\title{
LX. On the cultivation and manufacture of woad
}

\section{Mr. John Parrish}

To cite this article: Mr. John Parrish (1811) LX. On the cultivation and manufacture of woad, Philosophical Magazine Series 1, 38:163, 328-336, DOI: 10.1080/14786441108638660

To link to this article: http://dx.doi.org/10.1080/14786441108638660

曲 Published online: 27 Jul 2009.

6 Submit your article to this journal ש

Џ Article views: 2

Q View related articles $\sqsubset$ 


\section{On the Cultivation and Mamufacture of Woad.}

The Committee of Management should require the Nailsea colliers to put their works in such a state and condition, as to insure the working of 500 tons of coals per day at the least, as a sort of guarantee to the canal propriciurs for the risk of Jaying out immediately about $100,000 l$.

Messrs. Grace and Co.'s Colliery is heavily loaded with water, and by pricking additional feeders it would be drowned out; another Engine should be put up, to place them on a tolerable certainty. White's Colliery seems to be better off in regard to water, and a new engine of considerable power is erecting on the deep work.

At Teague's Colliery very little water has hitherto been met with, but in sinking deeper and in extending the work in every direction, feeders of water will surely be pricked, and that colliery cannot be considered out of danger till a fire engine is erected upois it.

The proposed collieries on Kenn-Moor, on Nailsea-Moor, and also on the lands of Sir Abraham Elton, Bart., to the southward of Clevedon church, should be opened.

\section{As to the Prospect of Collieries from Clevedon Hill to Morgan's Pill.}

A colliery was some years ago worked at Clapton, near the church, by virtue of a level which was brought up from the low grounds. The last pit upon the level head, was, I heard, nearly 40 fathoms deep, and the main vein when left was full six feet in thickness. Why it was abandoned, I know nut; and coal strata appear all along from Clapton church to Portbury church, where sundry veins of coal I have no doubt exist. A canal once opened into that vicinity, will certainly prompt persons to open those collieries, and with a fair prospect of success, after a canal is made ready to their hands.

(Signed) Edwand Martin, Colliery Surveyor, Morriston, near Swansea, July 31, 181 I.

LX. On the Cultivation and Manufacture of Woad. In a Letter to the President of the Bath and West of England Agricultural Society. By Mr. John Parrish*. Wo

OAD is a plant which, combined with indigo, gives the best and most permanent blue dye hitherto discovered. It is of great importance to our commerce, as well as to agriculture, being in nature one of the best preparers of

* From vol. xii, of the Society's Letters and Papers. 
land for a corn crop that has hitherto been discovered; and, if the land is properly chosen for it, and well managed, will be found very profitable, more particularly at this time, when its price is advanced to almost an unprecedented degree : therefore I conceive that in rendering its cultivation and preparation better known and understood, it may be greatly beneficial to the nation.

I have the honour to be a member of the Bath and West of England Agricultural Society, where many noble and exalted characters unite their talents to promote the public benefit. And to one of its earliest and most respectable members I presume to address this information.

I have been many years a considerable consumer of woad, and have also cultivated it with much success : and though I am well experienced in the usual method of its preparation, I was induced to depart from it in consequence of the great waste of its juices in the old method of grinding and balling. But I shall endeavour to give instructions for carrying on each process, and leave those who shall nndertake it to proceed as they think best.

This plant is cultivated in different parts of England for the use of the dyers, as well as in France, Germany, \&c. It is best to sow the seeds in the month of March, or early in April, if the season invite, and the soil be in condition to receive it ; but it requires a deep loamy soil, and is better still with a clay bottom, such as is not subject to become dry too quickly. It must never be flooded, but situated so as to drain its surface, that it may not be poisoned by any water stagnant upon it.

If (at any reasonable price) meadow land to break the turf can be obtained, it will be doubly productive. This land is generally freest from weeds and putrid matter, though sometimes it abounds with botts, grubs, and snails. However, it saves much expense in weeding; and judicious management will get rid of these otherwise destructive vermill. A season of warm showers, not too dry or too wet, gives the most regular crop, and produces the best woad.

If woad is sown on corn-land, much expense generally attends hoeing and weeding : and here it will require strong manure, though on leys it is seldom much necessary, yet land cannot be too rich for woad. On rich land dung should be avoided, particularly on leys, to avoid weeds. Some people sow it as grain, and harrow it in, and afterwards hoe it as turnips, leaving the plants at a distance in proportion to the strength of the land : others sow it in ranks by a drill- 
plough; and some dibble it in, (in quincunx form, by a stick with a peg crossways, about two or two and a half inches from the point, according to the land,) putting three or four seeds in a hole, and these holes to be from twenty inches to two feet apart, according to the richness of the land: for good land, if room be given, will produce very luxuriant plants in good seasons; but if too nearly planted, so that air cannot circulate, they do not thrive so well: attention to this is necessary in every way of sowing it. I have been most successful in this last process. Woad very often fails in its crop, from the land not being in condition, or from want of knowing how to destroy the botts, snails, wire-worms \&cc. that so often prey upon and destroy it, as well as from inattention to weeding, \&c. Crops fail also from being sown on land that is nalurally too dry, and in a dry season; but as the roots take a perpendicular direction, and run deep, such land as I have described (with proper attention to my observations) will seldom fail of a crop: and if the season will admit sowing eariy enough to have the plants strong before the dry and hot weather comes on, there will be almost a certainty of a great produce.

These plants are frequently destroyed in the germination by flies, or animalcula, and by grubs, snails, \&c. as before observed; and in order to preserve them, 1 have steeped the. seeds with good success in lime and sont, until they began to vegetate; first throwing half a load or more of flour lime $\%$ on the acre, and harrowing it in. Then plant the seeds as soon as they break the pod, taking care not to have more than one day's sced ready; for it is better to be too early, than to have their vegetation too strong before it is planted, lest they should rccive injury; yet I have never observed any injury in mine from this, though I have often scen the shoot strong. Fither harrows or rollers will close the holes. If the ground be moist it will appear in a few days; but it will be safe, and a benefit to the land, to throw more lime on the surface, when, if showers invite snails and grubs to eat it, they will be destroyed, which I have several times found; particularly once, when the leaves were two inches long, and in drills very thick and strong, but the ground was dry. When a warm rain fell, in less than two hours I found the ranks on one side attacked by these vermin, and enten entirely off by a large black grub, thousands of which were on the leaves, and they

* If the secds are not sown within a day after the time, it will lose much effect.

cleared 
cleared as they went, not going on until they had destrnyed every leaf where they fixed. They had eaten six or seven ranks before I was called by one of my people to observe it. Having plenty of lime, I immediately ordered it in flour to be strewed along those ranks which were not begun. This destroyed them in vast numbers, and secured the remainder. Another time, having had two succeeding crops on four acres of land, I considered it imprudent to venture another. However, as the land after this appeared so clean and rich, I again ventured, but soon found my error. On examining the roots (for after it had begun to vegetate strong, it was observed to decay and wither) I found thousands of the wire-worm at them, entwined in every root. I immcdiately strewed lime, (four loads, of six quarters each, on the four acres,) and harrowed it; when rain coming on soon after, washed it in, and destroyed them all, and gave me an extraordinary crop; but the first-sown side of the field, where they had begun, never quite recovered like the rest. And I am fully satisfied, that when the grub is seen in wheat, \&c. the same treatment (if the weather suited) would destroy them all, as well as change the nature of the land. I need not enter on the wide and extensive field of observations on the causes of weeds, grubs, \&c. (which so often counteract the labours of the husbandman,) that occur so differently in different seasons, and after different treatment and improper crops, - further than to ob. serve that when your land bas not a proper change, then it is that these are experienced in a more destructive degree.

Further, it is in vain to expect a grood crop of woad, of 2 good quality, from poor and shallow land. The difference of produce and its value is so great, that no one of any experience will waste his labour and attention on such lands upon so uncertain a produce. IVarm and moist seasons increase the quantity every where, but they can never give the principle which only good land affords.

In very wet seasons, woad from poor land is of very little value. I once bad occasion to purchase at such a time, and found that there was no possibility of regulating my vats in their fermentation; and I was under the necessity of making every possible effort to obtain some that was the produce of a more congenial season. I succeeded at last; but $I$ kept the other three and four years, when I found it more steady in its fermentation; but still it required a double quantity, and even then its effect was not like that from grood woad.

At this time several dyers experienced much difficulty, 


\section{On the Cultivation and Manufacture of Woad.}

and one of eminence in the blue-trade suffered so much by woad of his own growth, that he declared his resolution to decline the trade altogether. When I pointed out to him that it was the woad that occasioned his bad blues, and that I had from the same defect purchased such other woad as would do, and informed him where he could get it, - he succeedcd as usual. His own he disposed of to a drysalter, who sold it again somewhere in the country; and it occasioned such a cause of complaint, as I believe rendered the claim of payment to be given up, or partly so: of this I am not certain, having it only from report. I mention this in order to give those who wish to become growers of woad, such information as may properly direct them.

The leaves of woad on good land in a good season grow very large and long, and when they are ripe show near their end a brownish spot inclining to a purple towards its centre, while other parts of the leaves appear green, but just beginning to turn of a more yellowish shade; and then they must be gathered, or they will be injured.

Woad is to be gathered from twice to four and even five times in the season, as I once experienced (it was an early and a late scason), and for the next spring I saved an acre for seed, of which I had a fair crop. I picked the young seedling sprouts off the rest, and mixed with my first gathering of what was newly sown ; this was very good. During one season I let these shoots grow too long; the consequence was, that the fibrous parts became like so many sticks, and afforded no saponaceous juices. When you de. sign to plant woad on the same land the second season, it should be as soon as your last gathering (before winter is finished) be ploughed; that is, as soon as the weather will permit, and in deep furrows or ridges, to expose and ameliorate it by the vegetative salts that exist in the atmosphere, and by frost and snow. This, in some seasons, has partly the effect of a change of produce; but if intended for wheat, the last gathering should not be later than September.

The land, after woad, is always clean, and the nature of the soil appears to be greatly changed in favour of the wheat crop; for I have always experienced abundant increase of produce after woad, and observed that it held on for some time, if proper changes were attended to, and good husbandry. Keeping land clean from weeds, certainly produces an increase of corn; but in the hoeing and gathering woad (for hoeing and earthing up the plants often renders them abundantly more prolific, even if there are no weeds), znany nests of animalcula are destroyed, as well as grubs 
and insects, which are destructive to vegetation. All this is favourable to corn; but I am disposed to belicve that woad in itself furnishes such a principle of change in favour of corn (and wheat in particular), as in a high degree to merit the attention of that Society who are so honourably united to promote and encourage the first interests of the British empire.

Having said all I conceive necessary on the cultivation of woad, I now proceed to say something on its preparation for the use of the dyer.

Woad, when gathered, is carried to the mill, and ground. I need not describe this mill, becaluse they are to be seen in open sheds in several parts of Eugland, only that I conceive some improvement might be made in their construction, so as not so much to press out and waste the sap, which contains the very essence of the dyeing principle. These mills grind or cut the leaves small, and then they are cast into heaps, where they ferment, and gain an adhesive consistence* they are then formed into balls, as compact as possible, and placed on hurdles lying horizontally in a shed one over the other, with room for air between, to receive from the atmospheric air a principle which is said to improve them as a dye, as well as to dry them to a degree proper for being fermented; but in summer these balls are apt to crack in drying, and become fly-blown, when thousands of a peculiar maggot generate, and eat or destroy all that is useful to the dyer. Therefore they require attention as soon as any are observed to crack, to look them all over well, close them again, so as to render them as compact and solid as possible; and if the maggot or worm has already generated, some fine four lime strewed over it will destroy them, and be of much service in the fermentation. These balls, if properly preserved, will be very heavy; but if wormeaten, they will be very light, and of little value. They are then to be replaced on the hurdles, and turned, not being suffered to touch each other, until a month or more after the whole that is intended for one fermenting couch is gathered in, ground, and balled, and often until the hot weather of summer is past, to render the offensive opcration of turning it less disagreeable, and not so apt to overheat; and though temperature herein is necessary, yet a certain degree of heat must be attained, before it is in proper condition for the dyer's use. This is easily distinguished by a change or

* In a dry place, if these leaves remain a fortnight, being occasionally turned, they will become more adhesive, and have less juices to squeeze out in balling. The balls must be compact. 


\section{On the Cultivation and Manufacture of Woad.}

smell-from that which is most putrid and offensive, to one which is more agreeable and sweet, (if I may be allowed the term,) for few people at first either can approve of the smell of woad, or of a woad vat; though, when in condition, they become quite agreeable to those whose business it is to attend them. Woad is in this state of fermentation more or less time, according to the season and the degree of heat it is suffered to attain, whether at an early period, or according to the opinion of those who attend the process; but the best woad is produced from a heat temperately brought forward in the couch until at maturity, and turned, (on every occasion necessary,) which a proper degree of attention will soon discover.

These balls, when dry, are very hard and compact, and require to be broken to pieces with a mallet, and put into a heap, and watered to a due degree, only sufficient to promote fermentation, but not by too much moisture, which would retard it; and here is a crisis necessary to be attended to. When the couch has attained its due point, it is opened, spread, and turned, until regularly cooled, and then it is considered in contition for sale : but the immediate use of woad new from the couch is not advised by dyers who are experienced; for new woad is not so regular in its fermentation in the blue vat. This is the common process. Woad oftentimes is spoiled herein, by people who know nothing of the principles of its dye, following only their accustomed process of preparing it; and hence the difference in its quality is as often seen, as it is in the real richness or poverty of the leaves, from the quality of the land. The process for preparing woad which I have followed, and which I consider beyond all comparison best, is as follows :

Gather the leaves, put them to dry, and turn them, so as not to let them heat, and so be reduced to a paste; which, in fine weather, children can do. In wet weather, my method was to carry them to my stove, and when I had got a quantity sufficiently dry, I proceeded to the couch, and there put them in a large heap; where, if not too dry, they would soon begin to ferment and heat. If too wet, they would rot, but not properly ferment, nor readily hecome in condition for the dyer. These leaves not having been ground, nor placed in balls on the hurdles, their fermenting quality was more active, and required more attention; and also the application of lime occasionally to regulate the process with the same kind of judgement as used in the blue dying woad vat. When the beat increases too rapidly, turning is indispensably necessary, and the application of very fine flour 
lime regularly strewed over every laying of them; or, if the couch is getting too dry, lime-water instead of common water, applied by a gardener's watering-pot, may have an equal effect *, without loading the woad with the gross matter of the lime; though I conceive that the gross dry four lime, and the oxygen in the air, will furnish more carbonic acid gas to the woad, and retain such principles as are essential, to a better effect. For I bave experienced, that woad which requires the most lime to preserve a temperate degree of fermentation, and takes most time, is best, so that at length it comes to that heat which is indispensable to the production of good woad.

In this couch it is al ways particularly necessary to secure the surface as soon as the leaves begin to be reduced to a paste, by rendering it as smooth as possible, and free from cracks : this prevents the escape of much carbonic acid gas, (which is furnished by the lime and the fermentation,) and also preserves it from the fy, maggots, and worms, which often are seen in those parts where the heat is not so great, or the lime in sufficient quantity to destroy them; it is surprising to observe what a degree of heat they will bear. This attention to rendering the surface of the couch even and compact is equally necessary in either process, and to turning the woad exactly as a dung-heap, digging perpendicularly to the bottom. The couching-house should bave an even floor, of stone or brick, and the walls the same; and every part of the couch of woad should be beaten with the shovel, and trorlden, to render it as compact as possible.

The grower of woad should erect a long shed in the centre of his land, facing the south, the ground lying on a descent, so as to admit the sun to the back part; and here the woad should be put down as gathered, and spread thin at one end, keeping children to turn it towards the other end. In the course of a week, every day's gathering wil be dry for the couch, which should be at the other end; therefore it will be necessary to calculate how long the shed, should be; but this can be erected as you gather, and then it will soon be known.

I never used the thermometer to discover or determine the heat which is necessary to produce that change of smell which finishes a couch of woad properly for the dyert, but I am convinerd it cannot be regularly obtained but by temperance and time.

* There is in lime-water so little of its salt, that its effect is proportionably small, and water will take up but a certain quantity.

+ I suppose from 100 to 120 degrees. 
Good woad, such as the richest land produces, if properly prepared, will be of a blackish green, and mouldy; and when small lumps are pulled asunder, the fracture and fibres are brown; and these fibres will draw apart like small threads, and the more stringy they are, and the darker the external appearance and on the green hue, the better the woad; but poor land produces it of a light-brownish green. The fibres only serve to show that it has not suffered by putrefaction.

Considerable fortunes have been acquired by the culture of woad in the North of England, and those who have not in possession land sufficient of proper staple, will give an extra rent for leave to break pasturage; and such as is old, and its sod worn out and full of ant-hills from long feeding, is equally good, when lime is applied to destroy these and other insects, which here exist more than in such as is in full proof to bear grass; for here they generate and become destructive, so as often to render it very necessary to plough such land, corn it, and form a new turf; and though this is so often prohibited, yet it is often consistent with the best principles of husbandry. Here woad is every thing, and corn after it to a certain degree, which experience will determine, according to the kind of land. Those who grow woad in large quantities, have moveable huts for their workpeople; and also all their apparatus so easily put together, as to be of little expense except in carriage.

A friend of mine in London took a large quantity of land whereon had been wood just grubbed up. He planted woad on it, and engaged a person from the North to manage it; and the produce was so abundant as to afford immense profit. I believe he only woaded two years, and then let it. His tenant's produce did not by any means equal his, because the land began to want change. I know not how he succeeds in corn, but I presume he did well, as it is a fine preparative for it.

LXI. Geological Remarks and Queries on Dr. CAmperLl's $M a p$ and Account of the Stratification of Lancashire, in our last Number, p. 26s. By Mr. John Farey, Senior, Mineral Surveyor.

To Mr. Tilloch.

SIR, I was gratified, as I doubt not great part of your readers would be, at seeing a beginning made in your Philosophical and Geological Magazine, to sketch out the stra- 